\title{
Effects of Salvia miltiorrhiza injection on apoptosis of Schwann cells induced by hydrogen peroxide
}

\author{
Jingfei Zhong ${ }^{1}$, Jiaming Zhou ${ }^{1}$, Hui Sun ${ }^{1}$, Yinping $\mathrm{Wu}^{1}$, Ye $\mathrm{Wu}^{1}$, Meiyuan $\mathrm{Li}^{2}$ \\ ${ }^{1}$ Nantong University Xinglin College, Nantong, China; ${ }^{2}$ Key Laboratory of Neuroregeneration of Jiangsu Province and Ministry of Education, Co- \\ Innovatioin Center of Neuroregeneration, Nantong University, Nantong, China \\ Contributions: (I) Conception and design: M Li; (II) Administrative support: None; (III) Provision of study materials or patients: H Sun, Y Wu, Y \\ Wu; (IV) Collection and assembly of data: J Zhong; (V) Data analysis and interpretation: J Zhong; (VI) Manuscript writing: All authors; (VII) Final \\ approval of manuscript: All authors. \\ Correspondence to: Meiyuan Li. 19 Qixiu Road, Key Laboratory of Neuroregeneration of Jiangsu and Ministry of Education, Nantong University, \\ Nantong 226001, China. Email: limeiyuan1986@ntu.edu.cn.
}

Background Salvia miltiorrbiza is a traditional Chinese medicine with remarkable antioxidant, antibacterial, and anticoagulant properties. In the present study, we investigated the effects of Salvia miltiorrbiza injection in protecting Schwann cells (SCs) from hydrogen peroxide $\left(\mathrm{H}_{2} \mathrm{O}_{2}\right)$-induced cell apoptosis.

Methods: 3-(4,5-dimethylthiazol-2-yl)-2,5-diphenyltetrazolium bromide (MTT) assay and immunofluorescence staining were used to detect the establishment of the SC apoptosis model induced by $\mathrm{H}_{2} \mathrm{O}_{2}$. The effect of Salvia miltiorrhiza injection on injured cell morphology was observed, and the effect on cell apoptosis was determined by Annexin V-fluorescein isothiocyanate (FITC) apoptosis detection kit and terminal deoxynucleotidyl transferase-mediated dUTP nick end labeling (TUNEL) assay. Western blotting analysis was used to detect the effect of Salvia miltiorrbiza injection on apoptosis-related protein expression.

Results: The results of the MTT assay showed that cell activity significantly decreased after treatment with $1 \mathrm{mM} \mathrm{H} \mathrm{O}_{2}$, but different concentrations of Salvia miltiorrbiza injection could improve cell activity at different degrees. The number of cells increased significantly after treatment with Salvia miltiorrbiza injection. Annexin V-FITC/PI double staining and TUNEL results revealed that Salvia miltiorrbiza injection could significantly reduce apoptosis induced by $\mathrm{H}_{2} \mathrm{O}_{2}$. Western blotting analysis showed that the expression of Bcl-2 was significantly upregulated, while the expression level of Bax was significantly downregulated.

Conclusions: Salvia miltiorrhiza injection can protect SCs from $\mathrm{H}_{2} \mathrm{O}_{2}$-induced cell apoptosis, and has potential therapeutic effects in neurological disease.

Keywords: Salvia miltiorrbiza injection; Schwann cells (SCs); cell apoptosis; hydrogen peroxide $\left(\mathrm{H}_{2} \mathrm{O}_{2}\right)$

Submitted Nov 06, 2020. Accepted for publication Jan 25, 2021.

doi: 10.21037/apm-20-2580

View this article at: http://dx.doi.org/10.21037/apm-20-2580

\section{Introduction}

With the development of tissue engineering and molecular biology technology, research on peripheral nerve injury is now extensive (1-3). After peripheral nerve injury, the preservation of nerve cells and prevention of apoptosis are important for nerve regeneration. The gradual restoration of its regenerative ability depends on the microenvironment provided by the relevant cytokines. As an important glial cell in the peripheral nervous system, Schwann cell (SCs) play a key role in the process of nerve injury, regeneration, and repair $(4,5)$. Damage to SCs likely induces cell apoptosis, which will cause neurodegenerative diseases and restrict the functional recovery of peripheral nerves (6-8).

Various reactive oxygen species, such as superoxide anion, hydrogen peroxide $\left(\mathrm{H}_{2} \mathrm{O}_{2}\right)$, and nitric oxide, are 
all associated with cell apoptosis $(9,10)$. If the body overproduces these reactants, it will accelerate cell damage and tissue dysfunction. As a permeable membrane oxidant, $\mathrm{H}_{2} \mathrm{O}_{2}$ can freely diffuse into various cells and organelles, and induce oxidative stress effects, which may lead to mitochondrial dysfunction and ultimately destroy cell function integrity $(11,12)$. Many studies have found that the $\mathrm{SC}$ apoptosis induced by $\mathrm{H}_{2} \mathrm{O}_{2}$ can affect nerve regeneration $(13,14)$.

The advantages of traditional Chinese medicine are mainly reflected in the definite clinical efficacy and relatively safe medication, which has generated interest among researchers. In recent years, many studies have reported the protective effect of Salvia miltiorrbiza on myocardial ischemia-reperfusion injury, which fully shows that Salvia miltiorrbiza is widely used in the treatment of cardiovascular diseases and its anti-inflammatory and antiapoptotic effects (15-17). There are also studies to observe the protective effect of Salvia miltiorrbiza after exposing cardiomyocytes to $\mathrm{H}_{2} \mathrm{O}_{2}$, but there are few studies on the protective effect of Salvia miltiorrbiza on SCs with oxidative damage (18-20).

In the present study, we used an $\mathrm{H}_{2} \mathrm{O}_{2}$-induced SCs apoptosis model to investigate the potential protective role of different concentrations of Salvia miltiorrbiza injection. The findings indicated that Salvia miltiorrhiza injection can protect SCs from apoptosis caused by $\mathrm{H}_{2} \mathrm{O}_{2}$. We hope these findings could provide an experimental basis for the clinical application of Salvia miltiorrbiza.

We present the following article in accordance with the MDAR checklist (available at http://dx.doi.org/10.21037/ apm-20-2580).

\section{Methods}

\section{Ethics Statement}

Experiments were performed under a project license (No.: 20190303-15) granted by Laboratory Animal Ethics Committee of Nantong University, in compliance with Nantong University institutional guidelines for the care and use of animals.

\section{Cell culture}

SCs were cultured from the sciatic nerves of 1-day-old Sprague-Dawley rats, and digested by collagenase and trypsin, as previously described (21). The 1-day-old rats were acquired from the Experimental Animal Center of Nantong University [license No. SCXK (Su) 2014-0001 and SYXK (Su) 2012-0031, No. 20190225-004]. Briefly, the SCs were cultured in Dulbecco's modified Eagle's medium (DMEM) supplemented with $10 \%$ fetal bovine serum (Gibco, Grand Island, NY, USA) containing Recombinant Human NRG1- $\beta 1 /$ HRG1- $\beta 1$ (HRG) (R\&D System, Minneapolis, MN, USA) and forskolin (Sigma, St. Louis, MO, USA). Then anti-Thy1.1 antibody (Sigma, St. Louis, MO, USA) and rabbit complement (Invitrogen, Carlsbad, CA, USA) were further added to SCs isolated, and the purified SCs was observed and photographed.

\section{Immunofluorescence staining}

Cells were fixed in $4 \%$ formaldehyde for $15 \mathrm{~min}$ at room temperature. After washing with phosphate-buffered saline (PBS) twice; blocking solution was added at room temperature for $90 \mathrm{~min}$. After incubation with anti-S100 (1:500; Abcam) antibody at $4{ }^{\circ} \mathrm{C}$ overnight, the secondary antibody (donkey anti-mouse IgG-Alex-488, 1:200; Invitrogen) was incubated for $1 \mathrm{~h}$ at room temperature under dark conditions. After staining the nucleus with Hoechst 33258, the cells were observed under a fluorescence microscope (AxioImager M2; Zeiss).

\section{Cell treatment}

Prior to each experiment, $\mathrm{H}_{2} \mathrm{O}_{2}$ was freshly diluted to a $1 \mathrm{mM}$ final concentration with DMEM. Salvia miltiorrbiza injection (Zhengda Qingchunbao, China) was diluted into different concentrations $(1 / 160,1 / 80,1 / 40)$ with DMEM, according to the concentration of the stock solution $(1-1.5 \mathrm{~g} / \mathrm{mL})$. To determine the effect of Salvia miltiorrbiza injection, SCs were pretreated with Salvia miltiorrbiza injection for $24 \mathrm{~h}$, followed by co-treatment with $1 \mathrm{mM}$ $\mathrm{H}_{2} \mathrm{O}_{2}$ for $30 \mathrm{~min}$. In a single experiment, each treatment was performed in triplicate.

\section{Cell viability assay}

The cells were inoculated onto 96-well plates, and each group was subjected to corresponding treatment. A total of $20 \mu \mathrm{L}$ 3-(4,5-dimethylthiazol-2-yl)-2,5-diphenyltetrazolium bromide (MTT) was added to each well and cultured at $37^{\circ} \mathrm{C}$ for $4 \mathrm{~h}$. The supernatant was discarded, and $150 \mu \mathrm{L}$ dimethyl sulfoxide (DMSO) was added to each well and gently shaken. The light absorption value of each group was 

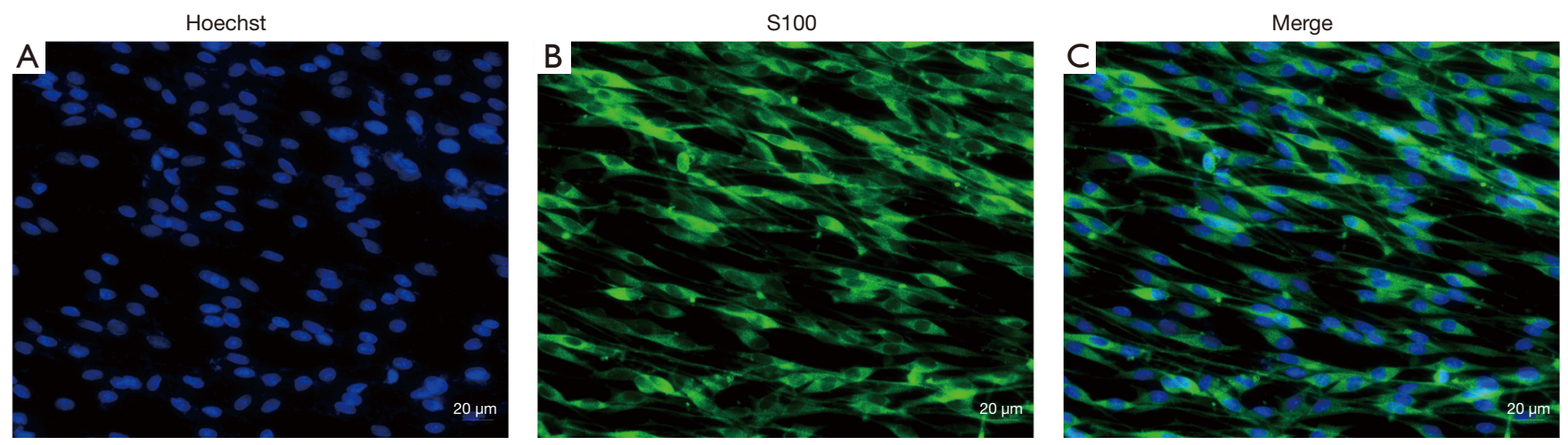

Figure 1 Immunocytochemistry identification of Schwann cells (SCs) in primary culture. (A) Hoechst 33342 staining; (B) S100 immunocytochemical staining; (C) Hoechst 33342 staining (blue) is combined with S100 (green) immunocytochemical staining. Scale bar $=20 \mu \mathrm{m}$.

determined at a wavelength of $490 \mathrm{~nm}$ with a microplate analyzer.

\section{Morphological observation of cells}

SCs were inoculated onto a 24-well plate at a density of $5 \times 10^{4} / \mathrm{mL}$. After the treatment of cells in each group, morphological changes of cells were observed under an inverted microscope. Six fields were randomly selected for each group, and the experiment was repeated 3 times.

\section{Flow cytometry}

To detect the apoptosis rate of SCs, flow cytometry apoptosis was detected in each group. Cells were resuspended in binding buffer and stained with $5 \mu \mathrm{L}$ Annexin V-FITC and $10 \mu \mathrm{L}$ propidium iodide (PI) at room temperature for 15 min under dark conditions. Apoptotic cells were analyzed by flow cytometry (BD Biosciences, San Jose, CA, USA), and the number of early apoptotic cells were calculated.

\section{Terminal deoxynucleotidyl transferase-mediated dUTP nick end labeling (TUNEL) assay}

Cells were seeded at a density of $2 \times 10^{5}$ cells $/ \mathrm{mL}$ with different treatments. TUNEL assay (Promega, Madison, WI, USA) was used to detect apoptotic cells. Hoechst 33342 was added for observation. The apoptotic rate was observed by calculating the number of TUNEL-positive cells in each field.

\section{Western blotting analysis}

After the cell model was established, the proteins of each group were extracted; $30 \mu \mathrm{g}$ cell proteins were separated on $10 \%$ sodium dodecylsulfate polyacrylamide gel electrophoresis (SDS-PAGE) and transferred to polyvinylidene fluoride (PVDF) membranes (Millipore, Bedford, MA, USA). After blocking for $2 \mathrm{~h}$ with $5 \%$ skim milk, anti-Bcl-2 (1:1,000; Abcam), anti-Bax (1:1,000; Abcam), and anti-GAPDH (1:5,000; Abcam) antibodies were added and incubated overnight at $4{ }^{\circ} \mathrm{C}$. The secondary antibody was incubated at room temperature for $1 \mathrm{~h}$, and protein data were analyzed.

\section{Statistical analysis}

All data are presented as mean \pm standard error. Statistical significance was conducted by one-way analysis of variance. Differences between groups were compared by $t$-test, and $\mathrm{P}<0.05$ was considered to be statistically significant.

\section{Results}

\section{Establishment of SC apoptosis model induced by $\mathrm{H}_{2} \mathrm{O}_{2}$}

The purity of primary cultured SCs was determined by immunochemistry with anti-S100 staining (Figure 1). After adding $1 \mathrm{mM} \mathrm{H}_{2} \mathrm{O}_{2}$ to the SCs for 15, 30, 60, and $120 \mathrm{~min}$, the cell activity decreased significantly. As shown in Figure $2 A$, an obvious decrease of viability was observed at 30 min with $1 \mathrm{mM} \mathrm{H}_{2} \mathrm{O}_{2}$ exposure $(51.3 \% \pm 1.01 \%$, compared with the control). Treatment with $1 \mathrm{mM} \mathrm{H} \mathrm{H}_{2} \mathrm{O}_{2}$ 

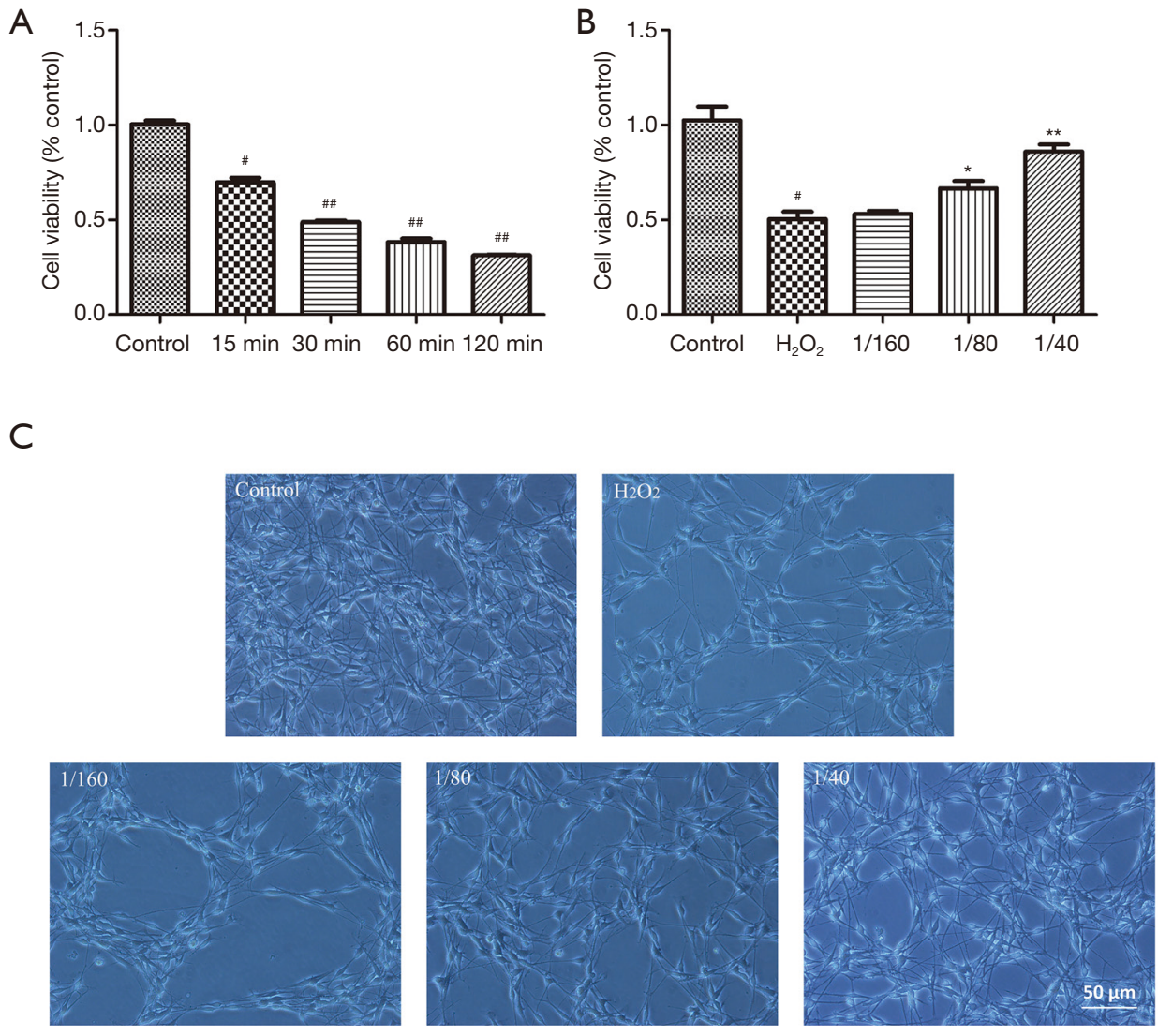

Figure 2 Effects of Salvia miltiorrbiza injection on viability in hydrogen peroxide $\left(\mathrm{H}_{2} \mathrm{O}_{2}\right)$-treated Schwann cells (SCs). (A) SCs were exposed to $1 \mathrm{mM} \mathrm{H}_{2} \mathrm{O}_{2}$ for the indicated times (15, 30, 60, $\left.120 \mathrm{~min}\right)$. (B) SCs were incubated with Salvia miltiorrbiza injection (1/160, 1/80, 1/40) for $24 \mathrm{~h}$, and $1 \mathrm{mM} \mathrm{H} \mathrm{O}_{2}$ was added for $30 \mathrm{~min}$. (C) Changes in $\mathrm{SC}$ morphology. ${ }^{*} \mathrm{P}<0.05,{ }^{* \#} \mathrm{P}<0.01$ vs. control cells. ${ }^{*} \mathrm{P}<0.05$, ${ }^{* *} \mathrm{P}<0.01$ vs. cells exposed to $\mathrm{H}_{2} \mathrm{O}_{2}$ alone. Scale bar $=50 \mu \mathrm{m}$.

for $30 \mathrm{~min}$ was used for subsequent experiments.

\section{Effect of Salvia miltiorrhiza injection on $\mathrm{H}_{2} \mathrm{O}_{2}$-induced cytotoxicity of SCs}

To evaluate the potential cytoprotective effect of Salvia miltiorrbiza injection against $\mathrm{H}_{2} \mathrm{O}_{2}$-induced SC death, SCs were pretreated with Salvia miltiorrbiza injection at various concentrations $(1 / 160,1 / 80,1 / 40)$ for $24 \mathrm{~h}$, followed by exposure to $\mathrm{H}_{2} \mathrm{O}_{2}$ at a final concentration of $1 \mathrm{mM}$ for $30 \mathrm{~min}$. As shown in Figure 2B, a low concentration of Salvia miltiorrhiza injection had no significant effect on the viability of apoptotic SCs, while moderate and high concentrations of Salvia miltiorrbiza injection increased the survival to $71.8 \% \pm 1.6 \%$ and $85.4 \% \pm 1.2 \%$, respectively $(\mathrm{P}<0.05)$. These data suggest that Salvia miltiorrbiza injection at these concentrations was not significantly cytotoxic.

\section{Effect of Salvia miltiorrbiza injection on $\mathrm{H}_{2} \mathrm{O}_{2}$-induced morphological changes of SCs}

After treatment with different concentrations of Salvia miltiorrbiza injection, we observed the morphology of SCs in each group. As shown in Figure 2C, cells in the control group had good morphology. The number of cells in the $\mathrm{H}_{2} \mathrm{O}_{2}$ group was significantly reduced, and shrinking and rounding of cell bodies and decreased connections between cells were observed. There was little change in cell number and morphology in the low concentration group. The number of cells in the moderate concentration group increased significantly. Compared with the moderate concentration group, the number of cells in the high concentration group increased more and the cells are better 
A
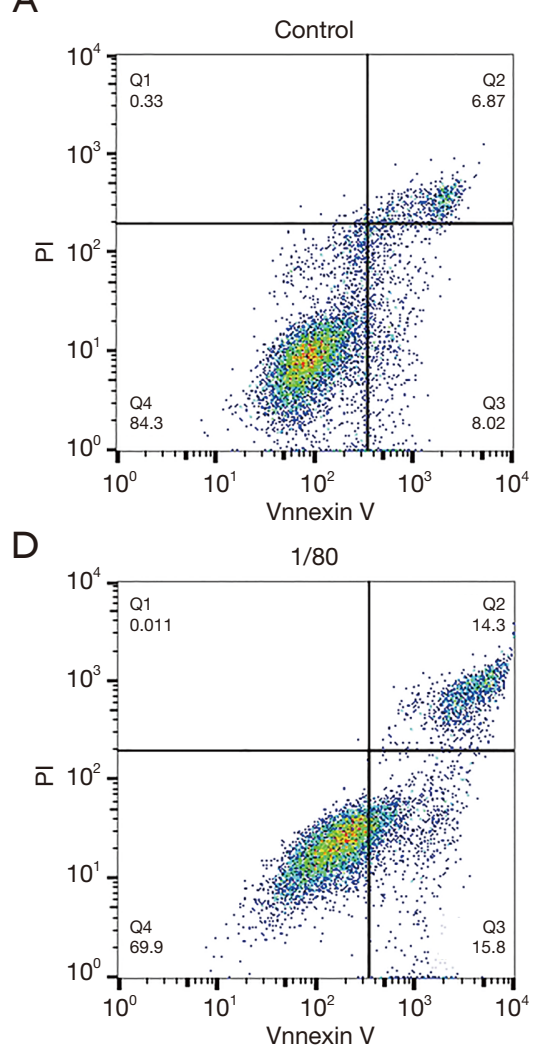

B

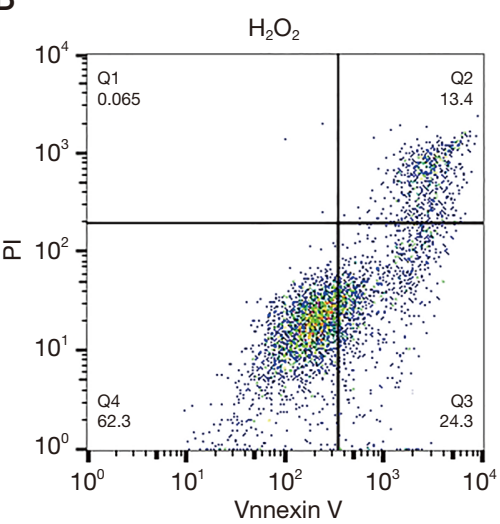

E

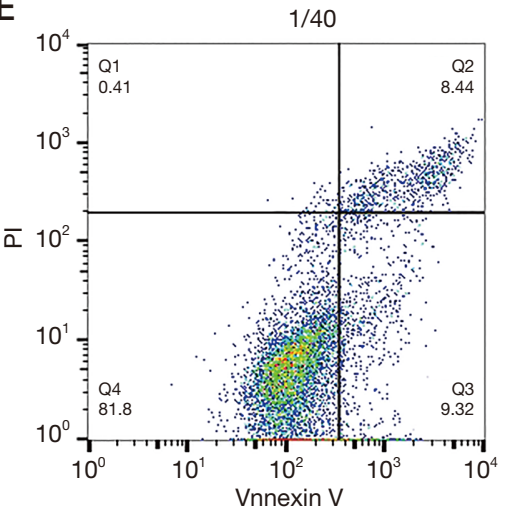

C

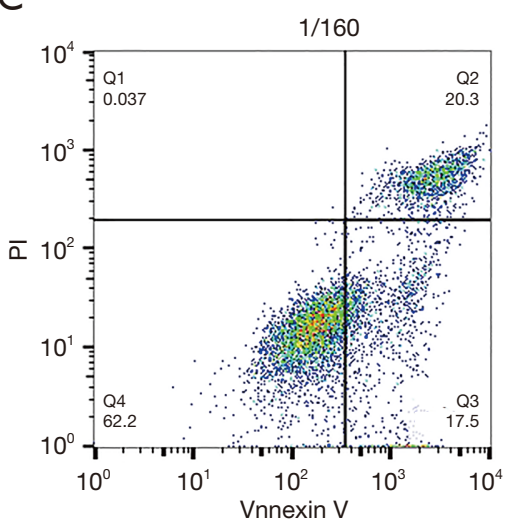

$\mathrm{F}$

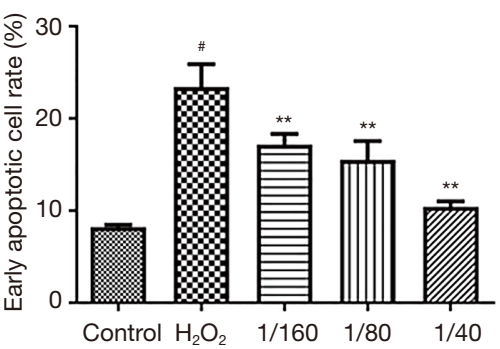

Figure 3 Effects of Salvia miltiorrbiza injection on hydrogen peroxide $\left(\mathrm{H}_{2} \mathrm{O}_{2}\right)$-induced cell apoptosis measured by flow cytometry. (A) Schwann cells (SCs) were cultured with normal medium. (B) SCs were exposed to $1 \mathrm{mM} \mathrm{H}_{2} \mathrm{O}_{2}$ for $30 \mathrm{~min}$. (C) SCs were incubated with Salvia miltiorrbiza injection at a concentration of $1 / 160$ for $24 \mathrm{~h}$, followed by co-treatment with $1 \mathrm{mM} \mathrm{H}_{2} \mathrm{O}_{2}$ for 30 min. (D) SCs were incubated with Salvia miltiorrbiza injection at a concentration of $1 / 80$ for $24 \mathrm{~h}$, followed by co-treatment with $1 \mathrm{mM} \mathrm{H}_{2} \mathrm{O}_{2}$ for 30 min. (E) SCs were incubated with Salvia miltiorrbiza injection at a concentration of $1 / 40$ for $24 \mathrm{~h}$, followed by co-treatment with $1 \mathrm{mM} \mathrm{H}_{2} \mathrm{O}_{2}$ for $30 \mathrm{~min}$. (F) The percentages of the rate of early apoptosis are shown by the histogram. Results are expressed as the mean \pm standard error of mean, $\mathrm{n}=5 .{ }^{\#} \mathrm{P}<0.05$, vs. control cells. ${ }^{* *} \mathrm{P}<0.01$ vs. cells exposed to $\mathrm{H}_{2} \mathrm{O}_{2}$ alone.

connected to each other.

\section{Salvia miltiorrbiza injection protects SCs against $\mathrm{H}_{2} \mathrm{O}_{2}$-induced cell apoptosis}

Flow cytometry results showed that the apoptosis of SCs increased rapidly in the $\mathrm{H}_{2} \mathrm{O}_{2}$ group. The number of apoptotic cells decreased significantly after treatment with different concentrations of Salvia miltiorrbiza injection, and the protective effect became more obvious with the drug concentration increase. Compared with the control group, the difference was statistically significant $(\mathrm{P}<0.01)$ (Figure 3). TUNEL-positive cells significantly increased from $3.78 \% \pm 1.05 \%$ (control) to $13.88 \% \pm 1.89 \%$ after exposure to $\mathrm{H}_{2} \mathrm{O}_{2}$ alone $(\mathrm{P}<0.01)$. After treatment with different concentrations of Salvia miltiorrbiza injection, the number of TUNEL-positive cells reduced to $9.03 \% \pm 1.92 \%$, $8.46 \% \pm 1.23 \%$, and $4.88 \% \pm 2.24 \%$, respectively $(\mathrm{P}<0.01)$ (Figure 4).

\section{Salvia miltiorrbiza injection inbibits apoptosis, as measured by Bax and Bcl-2 in SCs}

To confirm the protection of Salvia miltiorrbiza injection against $\mathrm{H}_{2} \mathrm{O}_{2}$-induced apoptosis, apoptosis-associated protein levels were measured. Treatment with different concentrations of Salvia miltiorrbiza injection significantly increased the expression of $\mathrm{Bcl}-2$ and significantly decreased 

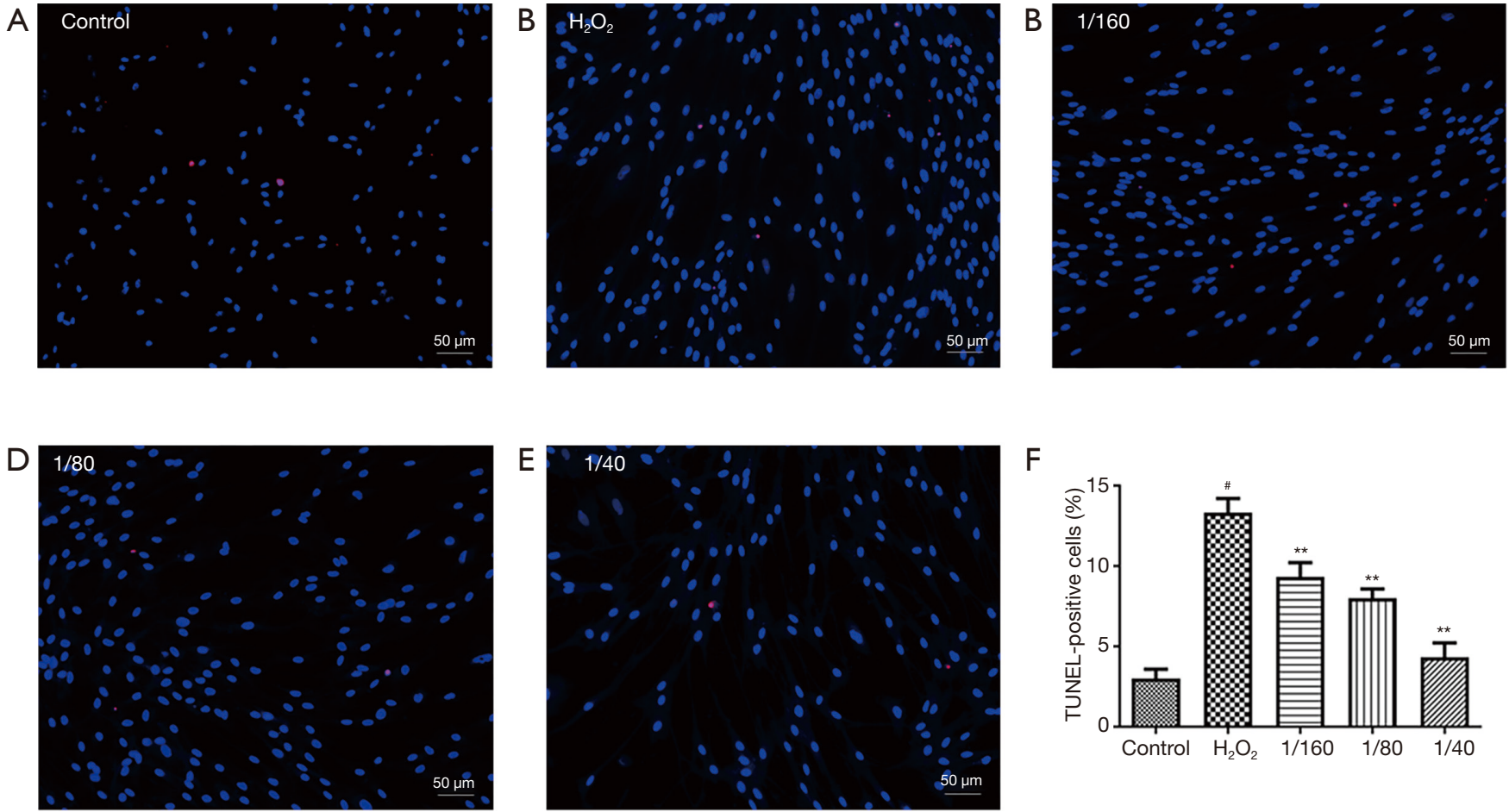

Figure 4 Effects of Salvia miltiorrbiza injection on hydrogen peroxide $\left(\mathrm{H}_{2} \mathrm{O}_{2}\right)$-induced cell apoptosis detected by terminal deoxynucleotidyl transferase-mediated dUTP nick end labeling (TUNEL) assay. (A) Schwann cells (SCs) were cultured with normal medium. (B) SCs were exposed to $1 \mathrm{mM} \mathrm{H}_{2} \mathrm{O}_{2}$ for $30 \mathrm{~min}$. (C) SCs were incubated with Salvia miltiorrbiza injection at a concentration of 1/160 for 24 h, followed by co-treatment with $1 \mathrm{mM} \mathrm{H} \mathrm{O}_{2}$ for $30 \mathrm{~min}$. (D) SCs were incubated with Salvia miltiorrbiza injection at a concentration of 1/80 for 24 h, followed by co-treatment with $1 \mathrm{mM} \mathrm{H} \mathrm{O}_{2}$ for $30 \mathrm{~min}$. (E) SCs were incubated with Salvia miltiorrbiza injection at a concentration of $1 / 40$ for $24 \mathrm{~h}$, followed by co-treatment with $1 \mathrm{mM} \mathrm{H}_{2} \mathrm{O}_{2}$ for $30 \mathrm{~min}$. (F) The percentages of TUNEL-positive cells are shown by the histogram. TUNEL-positive cells (red) under fluorescence microscopy; number of positive cells was counted. Results are expressed as the mean \pm standard error of mean, $\mathrm{n}=5 .{ }^{*} \mathrm{P}<0.05$, vs. control cells. ${ }^{* *} \mathrm{P}<0.01$ vs. cells exposed to $\mathrm{H}_{2} \mathrm{O}_{2}$ alone. Scale bar $=50 \mu \mathrm{m}$.

the expression of Bax compared with that of $\mathrm{H}_{2} \mathrm{O}_{2}$ treatment alone (Figure 5).

\section{Discussion}

Salvia miltiorrbiza is a well-known traditional Chinese medicine with many functions and effects, including enhancing myocardial contractility, regulating heart function and lowering blood lipids $(22,23)$. In the present study, we found that Salvia miltiorrbiza injection could protect SCs from $\mathrm{H}_{2} \mathrm{O}_{2}$-induced damage. To the best of our knowledge, our study is the first to report on the protective effect of Salvia miltiorrbiza injection on SCs during oxidative stress.

In the process of nerve regeneration, SCs can secrete a large number of growth factors to promote axon growth and myelin formation, which play a key role in peripheral nerve regeneration $(24,25)$. Oxidative stress can affect DNA synthesis and mitochondrial function, and completely destroy cell integrity. Therefore, apoptosis induced by oxidative stress is an important pathogenic factor in many neurodegenerative diseases (26).

In the present study, we constructed a $\mathrm{H}_{2} \mathrm{O}_{2}$ injury model in primary SCs to explore the protective effects of different concentrations of Salvia miltiorrbiza injection on SC apoptosis induced by $\mathrm{H}_{2} \mathrm{O}_{2}$. We found that Salvia miltiorrbiza injection can significantly improve the morphological changes and the viability of SCs exposed to $\mathrm{H}_{2} \mathrm{O}_{2}$. Annexin V-FITC/PI flow cytometry and TUNEL test results also showed that Salvia miltiorrbiza injection can inhibit the apoptosis of SCs induced by $\mathrm{H}_{2} \mathrm{O}_{2}$ in a dosedependent manner. In addition, it was also found that the expression of Bax and Bcl-2 both changed significantly after adding different concentrations of Salvia miltiorrbiza 


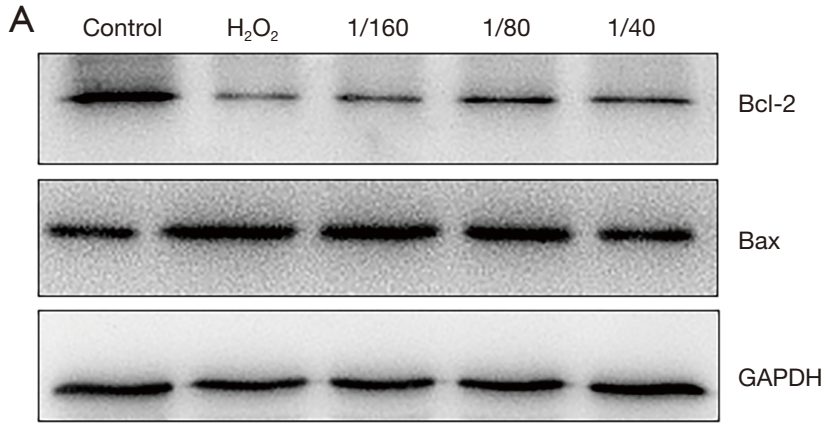

B

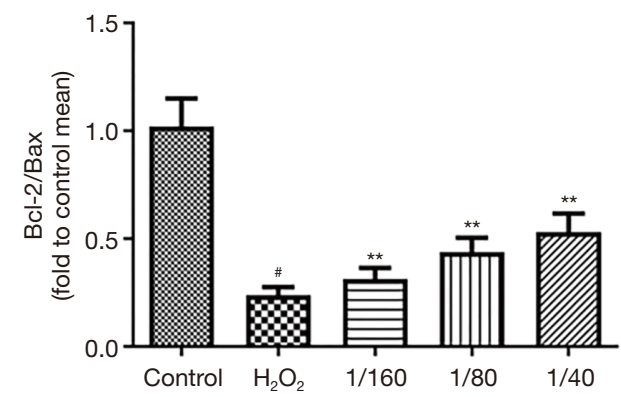

Figure 5 Salvia miltiorrhiza injection inhibited apoptosis measured by the protein levels in Schwann cells (SCs) exposed to hydrogen peroxide $\left(\mathrm{H}_{2} \mathrm{O}_{2}\right)$. (A) The level of Bax and Bcl-2 were measured by western blot. (B) Statistic analysis of (A). GAPDH was used as a loading control. Results are expressed as the mean \pm standard error of mean, $\mathrm{n}=5$. ${ }^{*} \mathrm{P}<0.05$, vs. control cells. ${ }^{* *} \mathrm{P}<0.01$ vs. cells exposed to $\mathrm{H}_{2} \mathrm{O}_{2}$ alone.

injection.

The findings of the present study indicate that different concentrations of Salvia miltiorrbiza injection can protect SCs from apoptosis caused by $\mathrm{H}_{2} \mathrm{O}_{2}$. The findings provide a basis for the application of Salvia miltiorrbiza in peripheral nerve injury repair, but further research on its molecular mechanism warrants further investigation.

\section{Acknowledgments}

Funding: This work was supported by grants from the Basic Research Project of the Jiangsu Education Department (Grant No. 19KJD310001, 18KJD310002), the Innovation and Entrepreneurship Training Program project for College Students of Jiangsu Province (Grant No. 201913993012Y), the National Natural Science Foundation of China (Grant No. 81901256), and the Science Foundation of Xinglin College, Nantong University (Grant No. 2016K135).

\section{Footnote}

Reporting Checklist: The authors have completed the MDAR reporting checklist. Available at http://dx.doi.org/10.21037/ apm-20-2580

Data Sharing Statement: Available at http://dx.doi. org/10.21037/apm-20-2580

Conflicts of Interest: All authors have completed the ICMJE uniform disclosure form (available at http://dx.doi. org/10.21037/apm-20-2580). The authors have no conflicts of interest to declare.

Ethics Statement: The authors are accountable for all aspects of the work in ensuring that questions related to the accuracy or integrity of any part of the work are appropriately investigated and resolved. Experiments were performed under a project license (No.: 2019030315) granted by Laboratory Animal Ethics Committee of Nantong University, in compliance with Nantong University institutional guidelines for the care and use of animals.

Open Access Statement: This is an Open Access article distributed in accordance with the Creative Commons Attribution-NonCommercial-NoDerivs 4.0 International License (CC BY-NC-ND 4.0), which permits the noncommercial replication and distribution of the article with the strict proviso that no changes or edits are made and the original work is properly cited (including links to both the formal publication through the relevant DOI and the license). See: https://creativecommons.org/licenses/by-nc-nd/4.0/.

\section{References}

1. Shabeeb D, Najafi M, Keshavarz M, et al. Recent Finding in Repair of the Peripheral Nerve Lesions Using Pharmacological Agents: Common Methods for Evaluating the Repair Process. Cent Nerv Syst Agents Med Chem 2018;18:161-72.

2. Hainline B. Peripheral nerve injury in sport: an overview. Handb Clin Neurol 2018;158:381-4.

3. Dong R, Liu Y, Yang Y, et al. MSC-Derived ExosomesBased Therapy for Peripheral Nerve Injury: A Novel Therapeutic Strategy. Biomed Res Int 2019;2019:6458237.

4. Ju DT, Liao HE, Shibu MA, et al. Nerve Regeneration Potential of Protocatechuic Acid in RSC96 Schwann 
Cells by Induction of Cellular Proliferation and Migration through IGF-IR-PI3K-Akt Signaling. Chin J Physiol 2015;58:412-9.

5. Jesuraj NJ, Santosa KB, Newton P, et al. A systematic evaluation of Schwann cell injection into acellular cold-preserved nerve grafts. J Neurosci Methods 2011;197:209-15.

6. Zhao Z, Li X, Li Q. Curcumin accelerates the repair of sciatic nerve injury in rats through reducing Schwann cells apoptosis and promoting myelinization. Biomed Pharmacother 2017;92:1103-10.

7. Liu CY, Yin G, Sun YD, et al. Effect of exosomes from adipose-derived stem cells on the apoptosis of Schwann cells in peripheral nerve injury. CNS Neurosci Ther 2020;26:189-96.

8. Nishio Y, Nishihira J, Ishibashi T, et al. Role of macrophage migration inhibitory factor (MIF) in peripheral nerve regeneration: anti-MIF antibody induces delay of nerve regeneration and the apoptosis of Schwann cells. Mol Med 2002;8:509-20.

9. Quan YY, Qin GQ, Huang H, et al. Dominant roles of Fenton reaction in sodium nitroprussideinduced chondrocyte apoptosis. Free Radic Biol Med 2016;94:135-44.

10. Wang Z, Li S, Cao Y, et al. Oxidative Stress and Carbonyl Lesions in Ulcerative Colitis and Associated Colorectal Cancer. Oxid Med Cell Longev 2016;2016:9875298.

11. Daverey A, Agrawal SK. Curcumin alleviates oxidative stress and mitochondrial dysfunction in astrocytes. Neuroscience 2016;333:92-103.

12. Jiang D, Fu C, Xiao J, et al. SGK1 Attenuates Oxidative Stress-Induced Renal Tubular Epithelial Cell Injury by Regulating Mitochondrial Function. Oxid Med Cell Longev 2019;2019:2013594.

13. He B, Wu F, Fan L, et al. Carboxymethylated chitosan protects Schwann cells against hydrogen peroxide-induced apoptosis by inhibiting oxidative stress and mitochondria dependent pathway. Eur J Pharmacol 2018;825:48-56.

14. Chao PY, Lin JA, Ye JC, et al. Attenuation of Oxidative Stress-Induced Cell Apoptosis in Schwann RSC96 Cells by Ocimum Gratissimum Aqueous Extract. Int J Med Sci 2017;14:764-71.

15. Su CY, Ming QL, Rahman K, et al. Salvia miltiorrhiza: Traditional medicinal uses, chemistry, and pharmacology. Chin J Nat Med 2015;13:163-82.

16. Ren J, Fu L, Nile SH, et al. Salvia miltiorrhiza in Treating Cardiovascular Diseases: A Review on Its Pharmacological and Clinical Applications. Front Pharmacol 2019;10:753.

17. Jin YC, Kim CW, Kim YM, et al. Cryptotanshinone, a lipophilic compound of Salvia miltiorrriza root, inhibits TNF-alpha-induced expression of adhesion molecules in HUVEC and attenuates rat myocardial ischemia/ reperfusion injury in vivo. Eur J Pharmacol 2009;614:91-7.

18. Yu YG, Yang J, Cheng XH, et al. The protection of acute spinal cord injury by subarachnoid space injection of Danshen in animal models. J Spinal Cord Med 2019;42:355-9.

19. Chang CC, Chang YC, Hu WL, et al. Oxidative Stress and Salvia miltiorrhiza in Aging-Associated Cardiovascular Diseases. Oxid Med Cell Longev 2016;2016:4797102.

20. Duan ZZ, Li YH, Li YY, et al. Danhong injection protects cardiomyocytes against hypoxia/reoxygenationand $\mathrm{H} 2 \mathrm{O} 2$-induced injury by inhibiting mitochondrial permeability transition pore opening. J Ethnopharmacol 2015;175:617-25.

21. Yu B, Qian T, Wang Y, et al. miR-182 inhibits Schwann cell proliferation and migration by targeting FGF9 and NTM, respectively at an early stage following sciatic nerve injury. Nucleic Acids Res 2012;40:10356-65.

22. Choi S, Tang A, Murthy S, et al. Preoperative Evaluation and Clinical Decision Making for Giant Paraesophageal Hernias: Who Gets an Operation? Thorac Surg Clin 2019;29:415-9.

23. Zhang J, Liang R, Wang L, et al. Effects and mechanisms of Danshen-Shanzha herb-pair for atherosclerosis treatment using network pharmacology and experimental pharmacology. J Ethnopharmacol 2019;229:104-14.

24. Wang H, Zhang P, Yu J, et al. Matrix metalloproteinase 7 promoted Schwann cell migration and myelination after rat sciatic nerve injury. Mol Brain 2019;12:101.

25. Webber CA, Christie KJ, Cheng C, et al. Schwann cells direct peripheral nerve regeneration through the Netrin-1 receptors, DCC and Unc5H2. Glia 2011;59:1503-17.

26. de Jager TL, Cockrell AE, Du Plessis SS. Ultraviolet Light Induced Generation of Reactive Oxygen Species. Adv Exp Med Biol 2017;996:15-23.

(English Language Editor: R. Scott)

Cite this article as: Zhong $\mathrm{J}$, Zhou $\mathrm{J}$, Sun $\mathrm{H}, \mathrm{Wu} \mathrm{Y}, \mathrm{Wu} \mathrm{Y}$, Li M. Effects of Salvia miltiorrhiza injection on apoptosis of Schwann cells induced by hydrogen peroxide. Ann Palliat Med 2021;10(1):625-632. doi: 10.21037/apm-20-2580 